\title{
More ACRL events in New York
}

The May 1996 issue of CERL News contained an insert listing ACRL programs, meetings, and special events taking place at the Al.A Annual Conference in New York. This brief list adds to those already published.

ACRL Anthropology and Sociology Section (ANSS) Twenty-fifth Anniversary Celebration/Reception. Monday, July 8, 6:00-7:30 p.m. at the John Jay College of Criminal Justice, 899 Tenth Ave., New York.

ANSS Tour of the American Museum of Natural History Library. Tuesday, July 9, 10:00 a.m.-12:00 noon. The tour will include the reference area, rare hook room, archives, art and memorabilia collection, and conservation laboratory, as well as storage areas and the digitization project for collection management in the Anthropology Department. The tour, which will be followed by a reception, is limited to the first 60 participants who advance register. To register send $\$ 5$ (checks made payable to Maija Lutz) to Maija M. Lutz, Tozzer Library, Harvard University, 21 Divinity Ave., Cambridge, MA 02138.

ACRL Instruction Section and LIR'T to honor Martin Raish. Monday, July 8, 9:30 a.m. Martin Raish, creator and moderator of the BI-L listserv, will receive a special certificate of recognition and appreciation at the joint IS/LIRT meeting. The certificate recognizes Raish's critical contributions to more than 2,300 BI-L listserv subscribers. The focus of $B I-L$ is on library instruction, with sulsstantive discussions, requests for advice and handouts, and reports on activities, new programs, and classrooms.

ACRL International Relations. Saturday, July 6, 9:00 a.m. Guests are welcome to the committee-led discussion on international librarianship that will look at questions such as: How can American librarians understand and make use of the experience of librarians in other countries? What is the "political culture" of libraries? How does the planned Glohal Information Infrastructure affect American and other librarians?

ACRL Science and Technology Section General Discussion Group. Sunday, July 7 , 2:00-4:00 p.m. Julie Arnott, SOLINET Preservation Services Manager, and Tom Clareson, AMIGOS Preservation Services Manager, will join the group.

ACRL Western European Specialists Section Scandinavian Discussion Group. Sunday, July 7, 4:30-5:30 p.m. Will discuss grant-funded, collaborative access and preservation projects focusing on the work at Cornell's Fiske Icelandic Collection.

in the May issue of College $\&$ Research Libraries, written by Carla J. Stoffle, Robert Renaud, and Jerilyn R. Veldof. The article and commentaries on it (provided by Susan Lee, Bonnie Jeuergens, and Richard Hume Werking) appear in an interactive form on the ACRI 8th National Conference Homepage at http://www.ala.org/acrl html.

"Choosing Our Futures" is the theme of the ACRL 8th National Conference, to be held in Nashville, April 11-14, 1997. Conference organizers would like your input on the future of libraries. Visit the conference homepage and follow the instructions for posting your comments and opinions.

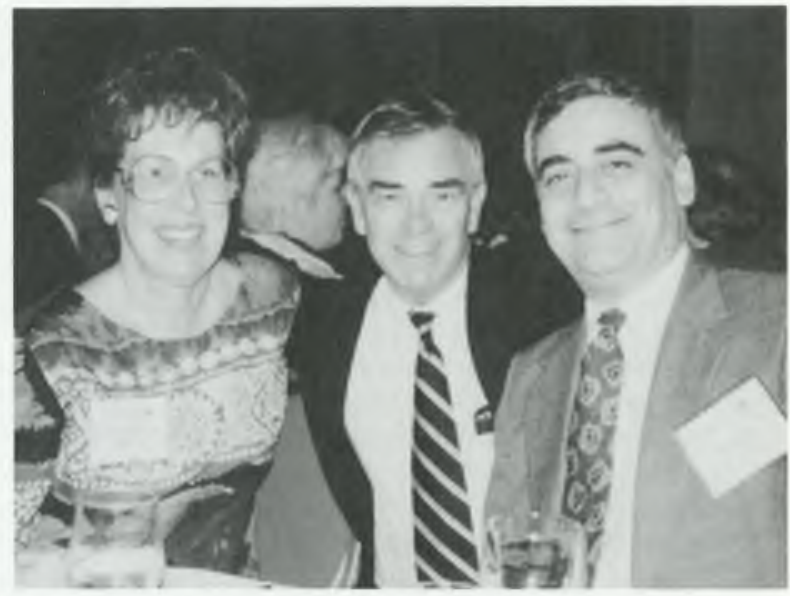

Patricia Senn Breivik (1) and William Miller ( $r$ ) enjoy the gala for the ALA Washington Office with Ralph Russell (center), ACRL's 1996 Academic/Research Librarian of the Year. 